\title{
Relationship Marketing: Advantages, Limitations and its Effect on the Customer Loyalty at University Hotels.
}

\author{
Ahmed Rady \\ Lecturer - Hotels studies Department \\ Faculty of Tourism and Hotels, Minia University
}

\section{Mohamed Adel Atia}

Lecturer - Hotels studies Department

Faculty of Tourism and Hotels, Minia University

\begin{abstract}
Relationship marketing is an important tool to overcome the marketing challenges related to environmental changing. The objective of this research is to study the structure, procedures, obstacles and the impact of relationship marketing system applied at the university hotels. This study was applied to university hotels in Middle Egypt governorates (Assuit, El Minia, Beni Suief and El Fayoum). The main hypothesis of this study was that "The relationship marketing procedures influences significantly the customer loyalty through the structure of relationship marketing system at university hotels". The research method adopted in this research combined two techniques; the first one was semi-structured interviews with the general managers and their assistants. The second technique applied questionnaire survey for university hotels' customers. The validity and reliability of the study tools were tested. The Cochran's formula was used to determine the optimal sample size based on the pilot study results. The study sample included all managers of studied hotels and a total number of 203 of customers. Data collected was analyzed statistically using SPSS version 21. The researchers used correlation and regression coefficients, variances analysis tests and path analysis test to test the validity of the study hypotheses. Results of the study indicated that; "There is a statistically significant effect of the relationship marketing procedures on customers' loyalty in the university hotels", this influence is separate from the effect of structure of the relationship marketing system in the university hotels, "There are statistical significance differences between university hotels at Middle Egypt with regard to the level of relationship marketing procedures" and "There are low levels of limitations in the use of relationship marketing with $95 \%$ confidence interval for mean at university hotels". The study tested the significance of the study model and equation that represents the influence of relationship marketing structure and procedures on customer loyalty at university hotels and suggested some recommendations.
\end{abstract}

Keywords: Relationship Marketing - University Hotels - Middle Egypt. 


\section{Introduction}

Relationship marketing is an approach for developing huge dealings with a firm's main stakeholders by encouraging mutual commitment, trust, long-term engagement and creating exchanges of mutually beneficial value (Badi, 2016 and Gummesson, 2010). The importance of this research is to study the use of marketing relationship at the university hotels as an important means to market these hotels especially located in Middle Egypt region, and to determine how to ensure the customers loyalty at these hotels.

\section{The study problem}

The relationship marketing approach in terms of comprehensive and accurate concept is not applied in general in most small and medium-sized enterprises (Badi, 2016). This problem was concluded from the pilot study that adopted at the beginning of the research, where it shows that most of the customers of the university hotels have low degree of loyalty to university hotels $(0.25$ for mean), additionally there is a lack of employees experience at these hotels concerning how to serve and maintain the customer loyalty ( 0.42 for mean). As well, according to the pilot study there is no clear system for the use of relationship marketing ( 0.2 for mean). Therefore, the problem of the study emerged from this perspective in how to attract, retain and strengthen the relationship with the current and new customers of university hotels.

\section{Objectives of the study}

1. Analyzing the structure and procedures of relationship marketing in the university hotels. 2. Measuring the impact of the relationship marketing system on University hotels customers' loyalty.

3. Identifying the obstacles of applying relationship marketing approach at University hotels. 4. Providing a proposed model for the study as well as a statistical equation showing the influences of the structure and procedures of relationship marketing on the customers' loyalty in the university hotels.

\section{Literature review}

\section{Relationship marketing}

According to Huang (2015), the definition of relationship marketing is including all marketing activities for establishing, developing and maintaining successful relational exchanges. In the past decade, relationship marketing investments improved customer trust, commitment and relationship satisfaction (Palmatier et al., 2009).

Cacciolutti and Lee (2016) agreed with Srivastava and Reibstein (2005) in that marketing has a vital role in determining the strategic orientation and performance outcomes of the strategic decisions. In addition, Dolnicar and Ring (2014) assured that marketing ties consumer needs and market offers. How marketing is perceived by consumers and suppliers is critical, where it must be perceived as advantageous by both sides (Gronroos, 2009).

Tripadvisor (2015) assured that hotel marketers need to revisit their approaches for building a positive and lasting relationship with all customer segments, in addition to encourage online 
booking and hotel brands through developing websites which attract customers and increase loyalty (Brlgihan, 2016).

Lee et al., (2015) referred that relationship marketing's role is prevalent in the hospitality industry by which service firms develop and sustain long-term relationships with valued customers. Relationship marketing allows service providers to treat selective customers differently with customized value and entertain that constantly changing service needs of customer, therefore creating competitive marketing advantages over competitors (Vargo and Lusch 2004).

The business institutions are adopting customer relationship marketing as a strategy to collect data for developing customer value and satisfaction. Also, companies are focusing on customer satisfaction rate that is considered a strong positive relationship between customer service quality and loyalty (Rashed, 2003).

\section{Customer satisfaction}

Customer satisfaction is a common research variable, due to its culminating effect on customers' future behaviors such as repurchasing and spreading positive reviews to potential new customers about a particular product or service (Jani and Han 2014).

Jani and Han (2011) agreed with Han and Ryu (2009) in that there are two factors affecting customer satisfaction; service environments perceived cost/price and consumption emotions. Lin (2010) referred that establishments which offer toys and video games for customers have a strong significant positive effect on customers' loyalty.

Orth et al., (2010) noted that there is a positive relationship between satisfaction and some key variables as experience, conscientiousness extraversion and agreeable emotions. Milfelner and Korda (2011) agreed with Lai et al., (2009) that the concept of customer satisfaction can be applied at the up and low levels. The overall satisfaction aspect of a hotel service affects determining guests' image and loyalty to a hotel services (Clemes et al., 2009).

The impact of customer satisfaction on customer' loyalty varies with the nature of the customer experience. Where, frequent customers have loyalty due to their image of services, while new customers' loyalty is motivated by their level of satisfaction (Brunner et al., 2009). Countryman and Jang (2006) stated that hotel guests' impressions point that atmospheric elements that include style, layout colors and lighting could change guests' image of a hotel over time.

Loyalty as a concept has been categorized into cognitive, affective, conative and action loyalty phases (Brunner et al., 2008). Relationship marketing is a considerable interest both to academics and practitioners (Gummesson, 2004). In a range of competitive industries including the hospitality and tourism sector, relationship management is seen as a sustainable competitive advantage that allows organizations to operate more effectively (Kim and Cha, 2002).

Relational bonds of relationship marketing have been defined as psychological, emotional, economic or physical attachments in a relationship that is fostered by association, interaction and service to bind parties together under relational exchange (Smith, 1998). Satisfaction is a person's feelings of pleasure or disappointment resulting from comparing his or her perception and expectation (Kotler, 2000). Baran et al. (2008) referred that satisfaction is a positive and affective 
behavior resulting from the appraisal of all aspects of other parties' working relationship. Meanwhile, in business dimension, guest satisfaction involves the apility of organization to maintain a positive relationship with its customers (Buttle, 2006).

There is a relationship between satisfaction and loyalty, where customer satisfaction is the mediating variable that might change the customers' status, whether they will become loyal or not (Abd Wahab et al., 2016).

\section{Guest Loyalty}

Mckercher et al., (2012) defined loyalty as a deeply held commitment to re-buy or re-patronize a preferred product/service consistently in the future, thereby causing repetitive same-brand purchasing despite situational influences and marketing efforts. Loyal customers are defined as frequent, repeat purchasers who feel a sense of belonging to an organization and who are reluctant to change even in the presence of similar offerings from other firms (Henry, 2000).

A loyal program which provides rewards that can be used for future purchase is a widely adopted promotion strategy by online retailers with the intention of increasing customer retention and resultant profits. However, the profit contribution of loyalty program in offline markets is highly controversial (Lim and Lee, 2015).

In the hospitality industry, the role of customer satisfaction is very important. The service-profit chain establishes this link between employee satisfaction, customer loyalty and productivity (Ineson et al., 2013). The objective of loyalty programs is to retain valued customers with a firm, additionally to make customers feel special, important and appreciated by rewarding them with preferential incentives (Lacey et al., 2007). In service environment loyalty programs, service quality and customer satisfaction are commonly recognized to be factors influence the formation of consumer loyalty (Shi et al., 2014).

Customer loyalty is a customer's attachment to a brand, store, manufacturer, service provider or other entities based on favorable attitudes and behavioral responses such as repeat purchase. In addition, customer loyalty is very essential to the organization in order to retain its current customers (Zakaria et al., 2014). Increase in customer loyalty will increase profits, reduced costs to acquire new customers. Also, the increasing competition, particularly in the service industry, has caused firms to become very concerned in attaching potential customers and typing to maintaining long-term relationships with their current customers (Abdul-Rahman and Kamarulzaman, 2012).

\section{Relationship marketing structure}

Berry (1995) defines three levels of relationship marketing; level one is relationship marketing using pricing stimuli or tangible benefits to keep customer loyalty, level two is relationship marketing adopting the social perspectives of a relationship which is conducted by regularly communicating with customers, a third level of relationship marketing offers solutions to the customer's problem and it is designed into the service-delivery system rather than relying on the relationship building skills. 
DebBrown (2017) stated that creating a plan for relationship marketing gives hotel's structure and system. Hotel can provide a repeatable experience to each contact on hotel list, thus every customer gets attention and feels appreciated. Seymour (2012) reported that there are many procedures that hotel can do to deal with its potential customers as follow: Focus on customer needs, be available, offer Information and resources, personalized greetings, provide ongoing support, be honest, show respect, customer appreciation and connect with customer.

\section{Relationship marketing procedures}

DebBrown (2017) agreed with Hashem (2012) and Nguyen (2006) in that relationship marketing has the following key procedures:

- Connection to the customers in trust way, where trust is an important component in establishing and maintaining successful inter organizational systems.

- Commitment in promises, it is a useful construct for measuring customer loyalty likelihood and predicting future purchase frequency.

- Social bonding, bonding is defined as the dimension of a business relationship between parties acting in a unified manner toward desired goal.

- Communication, it plays a central role in providing an understanding of the exchange partner's intensions and capabilities.

\section{Study conceptual model}

From the literature review, the researchers suggested the following model that explains the relationship and the influence of both variables "Relationship marketing procedure" and "Relationship Marketing Structure" on "Customer loyalty" at university hotels. The significance of regression and relationship coefficients will be tested during the study.

Figure 1: Study conceptual model

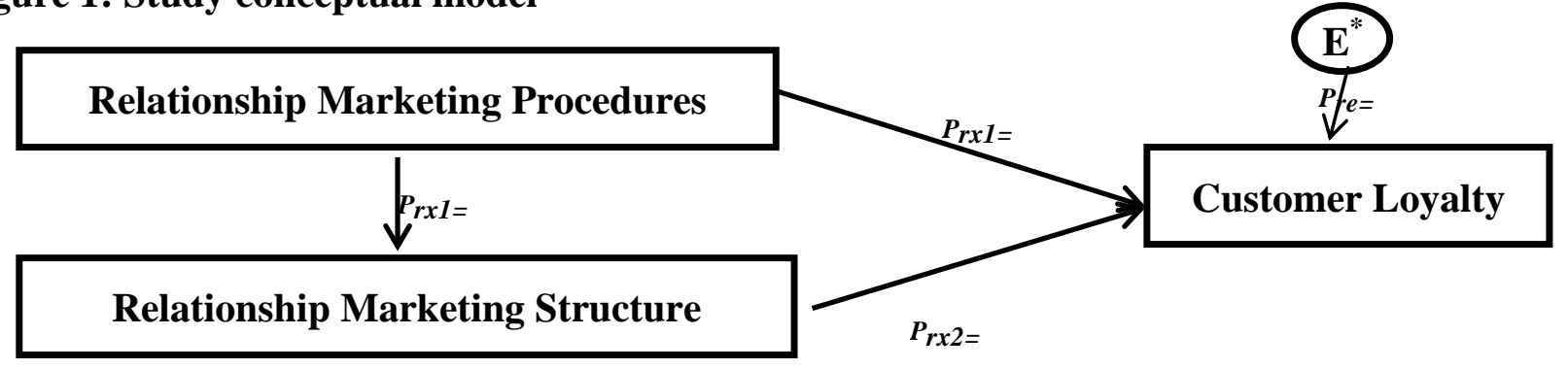

\section{Methodology}

The research method adopted in this research combined two techniques, the first one was semistructured interviews with the general managers and their assistants of university hotels at four governorates (Assuit, El Minia, Beni Suief, and El Fayoum) in order to determine the structure of the relationship marketing system, the relationship marketing procedures, level of customer loyalty and identify limitations in the use of relationship marketing at university hotels. Interviews with key elements of the organization are a way of ensuring an experienced vision of who is inserted in it and could induce a faster knowledge of what is analyzed (Paula et al. 2012). The 
second technique was the questionnaire survey for customers; respondents were users of all services that offered at university hotels, with the aim to understand the users' loyalty in relation to the relationship marketing structure and procedures. As a way to collect opinions and suggestions on the research tools, as well as the analysis of the same, a panel of experts in the field of hospitality management was consulted. Eighty customers' forms and eight managers' forms were distributed as a pilot study at Middle Egypt governorates (Assuit, El Minia, Beni Suief, and El Fayoum). Then the questionnaires were modified according to respondents' comments. Data collected from a pilot study have been tabulated and analyzed using SPSS 21 statistical package.

\section{Hypotheses}

1- The relationship marketing procedures influences significantly on the customer loyalty through the structure of relationship marketing system at university hotels.

2- There are no significant differences been the level of structure of relationship marketing system applied at university hotels and the standard level.

3- There are no significant differences between the level of relationship marketing procedures at university hotels and the standard level.

4- There are no significant differences between university hotels at Middle Egypt with regard to the level of relationship marketing procedures.

5- There are no significant difference between managers and customer's overview concerning the level of relationship marketing procedures applied at university hotels.

6- There are high levels of limitations in the use of relationship marketing with $95 \%$ confidence interval for mean at university hotels.

\section{Results}

Table 1: analyzing of pilot study data

\begin{tabular}{|l|l|l|l|l|}
\hline$\sigma^{2}$ & $Z$ & $\smile$ & $\begin{array}{l}\text { Levene's } \\
\text { Statistic }\end{array}$ & Levene's Sig. \\
\hline 0.13 & 1.96 & 0.05 & 2.6 & 0.12 \\
\hline
\end{tabular}

Table (1) show that Levene's coefficient is not significant Sig=0.12, Levene's test is used to assess the homogeneity for a variable calculated for research samples. If the resulting p-value of Levene's test is more than some significance level (the researchers used 0.05 significance level) the obtained equal variances in samples are likely to have occurred based on random sampling from a population with equal variances (Nodstokke and Zumbo, 2010). The researchers used Cochran's formula of sample size to calculate the research sample size as follows (Shkeeb, 2014):

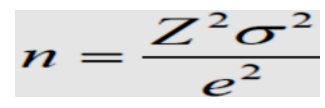

\section{Where:}

$\sigma^{2}$ : Variance of community $Z$ : Standard degree $\subset$ : Maximum allowed error

From the previous formula and table (1), the researchers calculated a convenient sample size for this research, where the maximum allowed error $(\mathbf{C})$ was 0.05 , this value is suitable for discrete 
data (Shkeeb, 2014), standard degree ( $Z$ ) was 0.05 and the variance of the sample $\left(\sigma^{2}\right.$ ) was 0.13. Applying these values to the Cochran's formula reveals that the appropriate sample size for this research is 200 participants. A total of 250 questionnaire forms were distributed to customers of university hotels at four governorates, only 225 customers positively shared the questionnaire. Among 225 received questionnaires, only 203 questionnaires were valid and complete. All managers are targeted and positively participated in an interview. The gathered data was checked, coded, entered into SPSS for analysis.

\section{Reliability Analysis}

Table 2: Reliability analysis of the independent variables used in the research

\begin{tabular}{|c|c|c|}
\hline The Axis & No. of statements & Alpha Coefficient \\
\hline The structure of relationship marketing system & 7 & 0.819 \\
\hline Relationship marketing procedures & 10 & 0.9 \\
\hline customer loyalty & 8 & 0.75 \\
\hline Limitations in applying relationship marketing & 3 & 0.8 \\
\hline
\end{tabular}

Table (2) indicated that each item has more than 0.7 Cronbach's Alpha, this means that all items are valid (Henson, 2001).

Table 3: Sample characteristic

\begin{tabular}{|l|l|l|l|}
\hline Variable & & No. & Percentage \\
\hline \multirow{3}{*}{ Respondents } & Managers & 8 & $4 \%$ \\
\cline { 2 - 4 } & Customers & 203 & $96 \%$ \\
\hline \multirow{3}{*}{ Region } & Assuit & 51 & $24 \%$ \\
\cline { 2 - 4 } & El Minia & 52 & $24.7 \%$ \\
\cline { 2 - 4 } & Beni Suief & 50 & $23.7 \%$ \\
\cline { 2 - 4 } & El Fayoum & 58 & $27.6 \%$ \\
\hline
\end{tabular}

The survey results showed that $8 \%$ was managers (eight managers) where all hotel managers participated in the interview and $96 \%$ was customers. A stratified sample was used where a population is split into four non-overlapping subpopulations (Paula et al. 2012), as shown in table (3) each governorate was roughly represented in terms of sample size.

Table 4: Managers Descriptive Statistics

\begin{tabular}{|l|l|l|l|}
\hline The Axis & Mean & $\begin{array}{l}95 \% \quad \text { Confidence } \\
\text { Interval for Mean* }\end{array}$ & Attitude \\
\hline The structure of relationship marketing system & 4,3 & $4 .-4.5$ & Strongly agree \\
\hline Relationship marketing procedures & 4.1 & $3.8-4.3$ & agree \\
\hline Customer Loyalty & 3,8 & $3.5-4.1$ & agree \\
\hline Limitations in applying relationship marketing & 2.66 & $2.1-3.1$ & disagree \\
\hline
\end{tabular}

$\mathbf{9 5 \%}$ Confidence Interval for Mean of the study population $=\bar{X} \mp t .0 .025,55 *$ Std.Error 
From the previous table it is obvious that $95 \%$ confidence interval for mean of the structure of relationship marketing system is between 4 as a lower bound and 4.5 as a Middle pound, 95\% confidence interval for mean of relationship marketing procedures is between 3.8 as a lower bound and 4.3 as a Middle pound, 95\% confidence interval for mean of customer loyalty is between 3.5 as a lower bound and 4.1 as a Middle pound and $95 \%$ confidence interval for mean of limitations in applying relationship marketing is between 2.1 as a lower bound and 3.1 as an Middle pound. This meant that there are low levels of limitations in the use of relationship marketing with $95 \%$ confidence interval for mean at university hotels and this result coincided that the sixth hypothesis of the study is invalid.

Table 5: Customer descriptive Statistics

\begin{tabular}{|l|l|l|l|}
\hline The Axis & Mean & $\begin{array}{l}95 \% \text { Confidence } \\
\text { Interval for Mean* }\end{array}$ & Attitude \\
\hline $\begin{array}{l}\text { The structure of relationship } \\
\text { marketing system }\end{array}$ & 3,4 & $3.3-3.5$ & Neither agree nor disagree \\
\hline $\begin{array}{l}\text { Relationship marketing } \\
\text { procedures }\end{array}$ & 3.5 & $3.4-3.7$ & Neither agree nor disagree \\
\hline customer loyalty & 3,7 & $3.6-3.8$ & agree \\
\hline
\end{tabular}

95\% Confidence interval for mean of the study population $=\bar{X} \mp t .0 .025,55 *$ Std.Error

Table (5) indicated that $95 \%$ confidence interval for mean of the structure of relationship marketing system is between 3.3 as a lower bound and 3.5 as an Middle pound, 95\% confidence interval for mean of relationship marketing procedures is between 3.4 as a lower bound and 3.7 as an Middle pound, $95 \%$ confidence interval for mean of customer loyalty is between 3.6 as a lower bound and 3.8 as an Middle pound.

To compare the point of view of managers and customers about the level of relationship marketing procedures applied at university hotels, an independent sample t-test was used as showed in table (6).

Table 6: Differences between managers and customers overview concerning the level of relationship marketing procedures applied at university hotels.

\begin{tabular}{|l|l|l|l|l|l|}
\hline \multirow{2}{*}{ Variable } & \multirow{2}{*}{ Group } & \multicolumn{2}{|l|}{ Levene's Test } & \multicolumn{2}{l|}{$\begin{array}{l}\text { t-test for Equality of } \\
\text { Means }\end{array}$} \\
\cline { 3 - 7 } & & F & Sig. & T & Sig. \\
\hline $\begin{array}{l}\text { relationship marketing } \\
\text { procedures }\end{array}$ & $\begin{array}{l}- \text { Managers } \\
\text { - customers }\end{array}$ & 2.2 & .139 & 5.3 & .000 \\
\hline
\end{tabular}

The results of table (6) shows that there are significant differences between managers and customers overview concerning the level of relationship marketing procedures applied at university hotels where Levene's Sig. is (0.139) and t-test Sig. is (0.000). This result coincided that the sixth hypothesis of the study is invalid. Concerning these differences, one could say that, it 
seems that there is a problem in mangers' understanding of customer attitudes and there are inadequate procedures used in relationship marketing applied at university hotels.

\section{Study variables analysis}

\section{The structure of relationship marketing system at university hotels}

The purpose of this variable was to measure the framework of the relationship marketing system applied at university hotels. The collected data is illustrated in table (7):

Table 7: Factor analysis of relationship marketing system at university hotels

\begin{tabular}{|l|c|}
\hline \multicolumn{1}{|c|}{ Statements } & Loadings \\
\hline Service quality is suitable to customer expectation & 0.98 \\
\hline There is a clear policy to deal with customer complains & 0.97 \\
\hline There is a continues studies to develop and enhance customer services & 0.99 \\
\hline The hotel interests in developing its internal marketing system & 0.99 \\
\hline $\begin{array}{l}\text { The hotel management focuses on developing its relationship with all its } \\
\text { customers without discrimination }\end{array}$ & 0.88 \\
\hline $\begin{array}{l}\text { There is a focus on building social relationships with customers and exploiting } \\
\text { social events to connect with them }\end{array}$ & 0.97 \\
\hline $\begin{array}{l}\text { There is a customer database that used to communicate with them even after } \\
\text { they leave the hotel }\end{array}$ & 0.92 \\
\hline Sums of squared loadings & 0.95 \\
\hline
\end{tabular}

Factor analysis shown in table (7) attempted to identify key variables or factors that explain the pattern of correlations within a set of observed variables. Statistical loading should not be less than 0.6 (Fabrigar, et al., 1999). Factor analysis showed that all seven elements were loaded on one factor explained $95 \%$ of the variation in the primary variable.

Table 8: Statistics for the structure of relationship marketing system at university hotels

\begin{tabular}{|l|l|l|l|}
\hline \multicolumn{1}{|c|}{ Statements } & M & SD & Sig. \\
\hline Service quality is suitable to customer expectation & 3.8 & 0.66 & 0.001 \\
\hline There is a clear policy to deal with customer complains & 3.4 & 0.82 & 0.000 \\
\hline There are continuous studies to develop and enhance customer services & 3.2 & 0.96 & 0.000 \\
\hline The hotel interests in developing its internal marketing system & 4.5 & 0.53 & 0.033 \\
\hline $\begin{array}{l}\text { The hotel management focuses on developing its relationship with all its } \\
\text { customers without discrimination }\end{array}$ & 3.3 & 0.9 & 0.000 \\
\hline $\begin{array}{l}\text { There is a focus on building social relationships with customers and } \\
\text { exploiting social events to connect with them }\end{array}$ & 3.5 & 0.8 & 0.000 \\
\hline $\begin{array}{l}\text { There is a customer database that used to communicate with them even } \\
\text { after they leave the hotel }\end{array}$ & 3.9 & 0.64 & 0.088 \\
\hline Statistics for all variables & 3.5 & 0.63 & 0.000 \\
\hline
\end{tabular}

M = Mean SD = Standard deviation Sig. = significance degree of one-sample T-Test 
Table (8) mentioned that the most effective variable was "The hotel interests in developing its internal marketing system", where the mean value was (4.5) and standard deviation was (0.53). On the other hand, the least effective variable was "There are continuous studies to develop and enhance customer services", where the mean value was (3.2) and standard deviation was (0.96). The overall mean of the above variables was (3.5), the standard deviation of means values was (0.63) and $\mathrm{p}$-value of one-sample T-test was (0.000) which indicated that there are significant differences between the structure level of relationship marketing system applied at university hotels and the test value (4), this value was selected because it was a suitable value that referred to a degree of "agreement". In the other word, respondents' awareness of all variables is less than the test value, this result coincided that the second hypothesis of the study is invalid.

\section{$\underline{\text { Relationship marketing procedures at university hotels }}$}

The purpose of this variable was to measure the relationship marketing procedures applied at university hotels. The collected data is illustrated in table 9:

Table 9: Factor Analysis of relationship marketing procedures applied at university hotels

\begin{tabular}{|l|c|}
\hline \multicolumn{1}{|c|}{ Statements } & Loadings \\
\hline The hotel connects to the customers even after leaving the hotel & 0.6 \\
\hline The hotel exploits various occasions to connect with customers & 0.6 \\
\hline The various means of communication (telephone, email, Facebook, etc.) are used. & 0.94 \\
\hline The hotel participates customers in the decisions of the services provided to them & 0.68 \\
\hline The hotel is interested in good treatment of customers in all positions & 0.67 \\
\hline The hotel management contributes positively to solve customers' problems & 0.7 \\
\hline The hotel management meets its promises to customers and check their expectations & 0.62 \\
\hline The hotel management develops positive individual relationships with consumers & 0.7 \\
\hline $\begin{array}{l}\text { The hotel management is studying and trying to understand the needs of the } \\
\text { customers and see what they think about constantly }\end{array}$ & 0.6 \\
\hline $\begin{array}{l}\text { The hotel gives incentives to employees when they satisfy the desires of a large } \\
\text { number of customers }\end{array}$ & 0.63 \\
\hline Sums of squared loadings & 0.66 \\
\hline
\end{tabular}

Factor analysis shown in table (9) stated that all ten elements were loaded on one factor and explained $66 \%$ of the variation in the primary variable.

Table 10: Statistics for relationship marketing procedures applied at university hotels.

\begin{tabular}{|l|l|l|l|}
\hline \multicolumn{1}{|c|}{ Statements } & \multicolumn{1}{|c|}{ M } & SD & \multicolumn{1}{|c|}{ Sig. } \\
\hline The hotel connects to the customers even after leaving the hotel & 0.36 & 0.69 & 0.000 \\
\hline The hotel exploits various occasions to connect with customers & 0.38 & 0.61 & 0.000 \\
\hline $\begin{array}{l}\text { The various means of communication (telephone, email, Facebook, etc.) } \\
\text { are used. }\end{array}$ & 4.1 & 2.8 & 0.558 \\
\hline $\begin{array}{l}\text { The hotel participates customers in the decisions of the services provided } \\
\text { to them }\end{array}$ & 3.1 & 0.9 & 0.000 \\
\hline The hotel is interested in good treatment of customers in all positions & 3.2 & 0.9 & 0.000 \\
\hline
\end{tabular}




\begin{tabular}{|l|l|l|l|}
\hline The hotel management contributes positively to solve customers' problem & 3.3 & 0.99 & 0.000 \\
\hline $\begin{array}{l}\text { The hotel management meets its promises to customers and check their } \\
\text { expectations }\end{array}$ & 3.5 & 0.82 & 0.000 \\
\hline $\begin{array}{l}\text { The hotel management develops positive individual relationships with } \\
\text { consumers }\end{array}$ & 3.3 & 0.93 & 0.000 \\
\hline $\begin{array}{l}\text { The hotel management is studying and trying to understand the needs of } \\
\text { the customers and see what they think about constantly }\end{array}$ & 3.7 & 0.62 & 0.000 \\
\hline $\begin{array}{l}\text { The hotel gives incentives to employees when they satisfy the desires of a } \\
\text { large number of customers }\end{array}$ & 3.8 & 0.89 & 0.451 \\
\hline Statistics for all variables & 3.5 & 0.64 & 0.000 \\
\hline
\end{tabular}

M = Mean SD = Standard deviation Sig. = significance degree of one-sample T-Test

Table (10) indicated that the most effective variable was "The various means of communication (telephone, email, Facebook, etc.) are used", where the mean value was (4.1) and standard deviation was (2.8). On the other hand, the least effective variable was "The hotel participates customers in the decisions of the services provided to them", where the mean value was (3.1) and standard deviation was (0.9). The overall mean of the above variables was (3.5), the standard deviation of means values was (0.64) and p-value of one-sample T-test was (0.000) which indicated that there are significant differences between the relationship marketing procedures applied at university hotels and the test value (4), this value was selected because it was a suitable value that referred to a degree of "agreement". In the other word, respondents' awareness of all variables is less than the test value, this result coincided that the third hypothesis of the study is invalid.

\section{Customer loyalty at university hotels}

The purpose of this variable was to measure the customer loyalty at university hotels. The collected data is illustrated in table 11 .

Table 11: Factor Analysis of the customer loyalty at university hotels

\begin{tabular}{|l|l|}
\hline \multicolumn{1}{|c|}{ Statements } & Loadings \\
\hline There is positive customers behavior towards the hotel & 0.82 \\
\hline Costumers deal with the Hotel frequently & 0.8 \\
\hline The hotel offers all the services that meet the needs of the customers & 0.7 \\
\hline Customer satisfaction is periodically analyzed and solutions are found & 0.76 \\
\hline The concentration is more on customer loyalty than on profitability & 0.6 \\
\hline $\begin{array}{l}\text { The adoption of relationship marketing helps to improve the mental image of } \\
\text { customer s about university hotels }\end{array}$ & 0.75 \\
\hline Customer spending increases on hotel services when repeating the visit & 0.6 \\
\hline Customers of university hotels use the word of mouth to market their services & 0.61 \\
\hline Sums of squared loadings & 0.67 \\
\hline
\end{tabular}

Table (11) stated that all eight elements were loaded on one factor explained $67 \%$ of the variation in the primary variable. 
Table (12): Statistics for the customer loyalty at university hotels

\begin{tabular}{|l|l|l|l|}
\hline Statements & M. & SD & Sig. \\
\hline There is positive customers behavior towards the hotel & 4.1 & 0.48 & 0.001 \\
\hline Costumers deal with the Hotel frequently & 4.2 & 0.51 & 0.000 \\
\hline The hotel offers all the services that meet the needs of the customers & 3.3 & 0.9 & 0.000 \\
\hline Customer satisfaction is periodically analyzed and solutions are found & 3.2 & 0.9 & 0.008 \\
\hline The concentration is more on customer loyalty than on profitability & 2.6 & 1 & 0.000 \\
\hline $\begin{array}{l}\text { The adoption of relationship marketing helps to improve the mental image of } \\
\text { customer s about university hotels }\end{array}$ & 3.4 & 0.94 & 0.000 \\
\hline Customer spending increases on hotel services when repeating the visit & 3.8 & 0.67 & 0.000 \\
\hline $\begin{array}{l}\text { Customers of university hotels use the word of mouth to market their } \\
\text { services }\end{array}$ & 3.9 & 0.61 & 0.504 \\
\hline Statistics for all variables & 3.7 & 0.51 & 0.000 \\
\hline
\end{tabular}

M = Mean SD = Standard deviation Sig. = significance degree of one-sample T-Test

Table (12) showed that the most effective variable was "Costumers deal with the Hotel frequently", where the mean value was (4.2) and standard deviation was (0.51). On the other hand, the least effective variable was "The concentration is more on customer loyalty than on profitability", where the mean value was (2.6) and standard deviation was (1). The overall mean of the above variables was (3.7), the standard deviation of means values was (0.51) and p-value of one-sample T-test was (0.000) which indicated that there are significant differences between the customer loyalty at university hotels and the test value (4), this value was selected because it was a suitable value that referred to a degree of "agreement". In the other word, there is a low level of customer loyalty at university hotels.

\section{Limitations in the use of relationship marketing at university hotels}

The purpose of this variable was to study the limitations in the use of relationship marketing at university hotels. This variable was negatively coded, because it speaks negative as opposed to other questions, since for analysis the researchers need to have all questions either positive or negative so as to get proper, so the data of this variable was recoded. The collected data is illustrated in table 13:

Table 13: Factor Analysis of the limitations in the use of relationship marketing at university hotels

\begin{tabular}{|l|l|}
\hline \multicolumn{1}{|c|}{ Statements } & Loadings \\
\hline $\begin{array}{l}\text { It is difficult to communicate with customers because of the privacy of their } \\
\text { information. }\end{array}$ & 0.6 \\
\hline The weakness of technological capabilities impede communication with customers & 0.7 \\
\hline The weakness of staff experience hinders good customer relationship & 0.61 \\
\hline The lack of training courses for staff hinders good communication with customers & 0.2 \\
\hline Sums of squared loadings & 0.66 \\
\hline
\end{tabular}

Table (13) stated that just three elements were loaded with value exceeded (0.6) on one factor explained $66 \%$ of the variation in the primary variable. Just one variable was loaded with value less than (0.6), so that, the researchers deleted it. 
Table 14: Statistics for the limitations in the use of relationship marketing at university hotels

\begin{tabular}{|l|l|l|l|}
\hline \multicolumn{1}{|c|}{ Items } & M & SD & Sig. \\
\cline { 1 - 4 } Statements & & & \\
\hline $\begin{array}{l}\text { It is difficult to communicate with customers because of the privacy of } \\
\text { their information. }\end{array}$ & 2.25 & 0.88 & 0.001 \\
\hline $\begin{array}{l}\text { The weakness of technological capabilities impede communication with } \\
\text { customers }\end{array}$ & 2.5 & 1.3 & 0.0014 \\
\hline The weakness of staff experience hinders good customer relationship & 3.25 & 1.38 & 0.17 \\
\hline Statistics for all variables & 2.66 & 0.56 & 0.000 \\
\hline
\end{tabular}

M = Mean SD = Standard Deviation Sig. = significance degree of one-sample T-Test

Table (14) showed that the overall mean of the above variables was (2.66) and the standard deviation of means values was (0.56) which indicated the low level of limitations in the use of relationship marketing at university hotels. The most effective limitation was "The weakness of staff experience hinders good customer relationship", where the mean value was (3.25), standard deviation (0.49) and p-value was (0.170), this mean that there are no significant differences between the weakness of staff experience at university hotels and the test value (4), on the other word, there is a lack of employees experience at university hotels. On the other hand, the least effective variable was "It is difficult to communicate with customers because of the privacy of their information", where the mean value was (2.25) and standard deviation was (0.88). This means that communicating with customers using their information as a marketing relationship tool is constantly available. The overall mean of the above variables was (2.66), the standard deviation of means values was (0.56) and p-value of one-sample T-test was $(0.000)$ which indicated that there are significant differences between the limitations in the use of relationship marketing at university hotels and the test value (4), this value was selected because it was a suitable value that referred to a degree of "agreement". In the other word, there is a low level of limitations in the use of relationship marketing at university hotels, this result also coincided that the fifth hypothesis of the study is invalid.

To test the first hypothesis of the study, path analysis was used. Path analysis is a good presentation tool to estimate a set of simultaneous regression equations where there are intermediate variables and indirect effects because the causal variables are correlated (Akintuned, A., 2012), to make a path analyses, Pearson correlation coefficient and beta regression coefficients were tested as shown in tables (15), (16):

Table 15: Correlation between relationship marketing procedures and relationship marketing structure

\begin{tabular}{|ll|c|}
\hline \multicolumn{2}{|c|}{ Variables } & Relationship marketing procedures \\
\hline Relationship & marketing & Pearson Correlation \\
structure & & Sig. (2-tailed) \\
& $\mathrm{N}$ & $0.722 * *$ \\
& & 211 \\
\hline
\end{tabular}

"Correlation is significant at the 0.01 level (2-tailed). 
Table 16: Multiple regression coefficients for influence of relationship marketing structure and relationship marketing procedures on customer loyalty

\begin{tabular}{|l|c|c|c|c|}
\hline Model & $\mathrm{R}^{2}$ & Beta & $\mathrm{T}$ & Sig. \\
\hline Constant) & & & 9.805 & .000 \\
Relationship marketing structure & 0.589 & 0.385 & 5.994 & .000 \\
Relationship marketing procedures & & 0.441 & 6.867 & .000 \\
\hline
\end{tabular}

a. Dependent variable: customer loyalty

From tables (15) and (16) the, $(\mathrm{R})$ value (0.772) referred that there is a strong degree of correlation between relationship marketing structure and relationship marketing procedures at university hotels, as well as the coefficient of determination $\left(\mathrm{R}^{2}\right)$ is $(0.589)$, suggesting that $58.9 \%$ of the variation of customer loyalty was explained by the both variables (relationship marketing structure and relationship marketing procedures) at university hotels. The following path analysis model can be drawn to illustrate these influences.

Model 1: Path analysis model for the influences of relationship marketing structure and relationship marketing procedures on the customer loyalty at university hotels

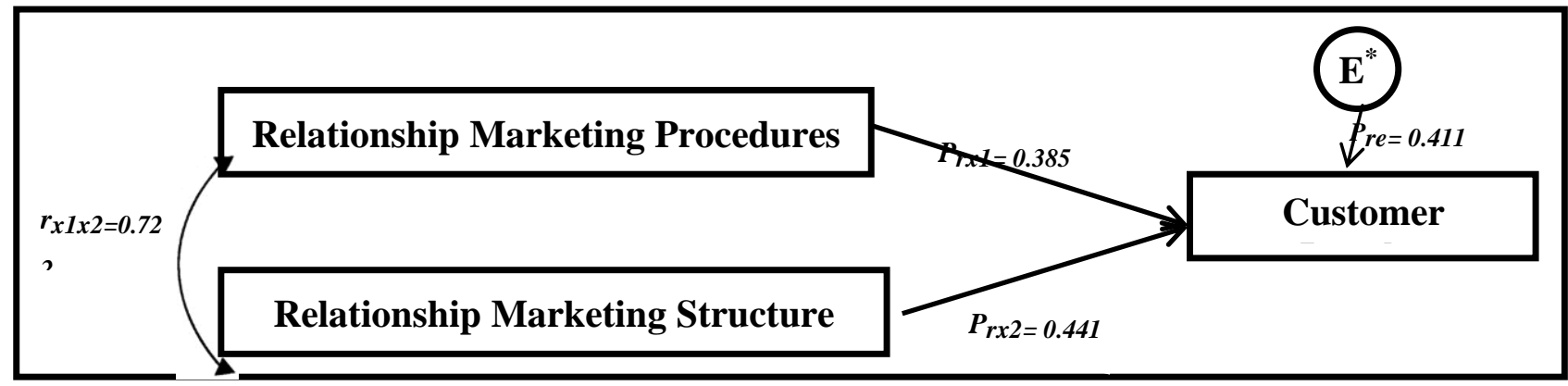

Source: researchers design

${ }^{*}$ Epsilon beta coefficient $=1-\mathbf{R}^{2}$

From the previous model, the following equation can be inferred to predict the customer loyalty from both variables (relationship marketing structure and relationship marketing procedures) as follow:

Equation 1: The influences of relationship marketing structure and relationship marketing procedures on the customer loyalty at university hotels

\section{Customer loyalty $=\mathbf{0 . 3 8 5}$ relationship marketing structure $+\mathbf{0 . 4 4 1}$ relationship marketing procedures $+\mathbf{0 . 4 1 1}$}

Source: researchers design

Mediator multiple regression was tested, where a mediation analysis is typically conducted to better understand an observed correlation between $\mathrm{X}$ variable and $\mathrm{Y}$ variable (MacKinnon et.al, 
2007). On the other word, this analysis used to test if "the relationship marketing structure" variable is a mediator that controls the significance of the previous model.

Table (17): Regression coefficients for influence of relationship marketing structure on relationship marketing procedures

\begin{tabular}{|l|c|c|c|c|}
\hline Model & R Square & Beta & t & Sig. \\
\hline (constant) & 0.496 & 0.704 & $\begin{array}{c}11.637 \\
14.333\end{array}$ & .000 \\
Relationship marketing procedures & & & .000 \\
\hline
\end{tabular}

From the results of table (16) and table (17), it seems that all regression coefficients statistically significant, $\mathrm{P}<0.05$, so the variable of (relationship marketing structure) is consider as partial mediation not all mediation because the direct effect (relationship marketing procedures) is still significant after adding the mediator (relationship marketing structure) into the regression equation. This result coincided that the first hypothesis of the study is invalid. That means that relationship marketing procedures do not applied at a systematic relationship marketing structure at university hotels.

To test fourth hypothesis ANOVA test was used as follows:

Table (18): Differences between university hotels at Middle Egypt with regard to the level of relationship marketing procedures

\begin{tabular}{|l|c|c|c|c|c|}
\hline \multicolumn{1}{|c|}{ procedures } & Sum of Squares & Df & Mean Square & F & Sig. \\
\hline Between Groups & 28.252 & 3 & 9.417 & 33.484 & .000 \\
Within Groups & 58.218 & 207 & .281 & & \\
Total & 86.470 & 210 & & & \\
\hline
\end{tabular}

From the previous table it obvious that sig. value is $(0.000)$ that means that there are significant differences between university hotels at Middle Egypt with regard to the level of relationship marketing procedures. This result coincided that the fourth hypothesis of the study is invalid.

\section{Study model and equation}

The study tested the significance of the following model and equation:

figure 2: The study model and equation

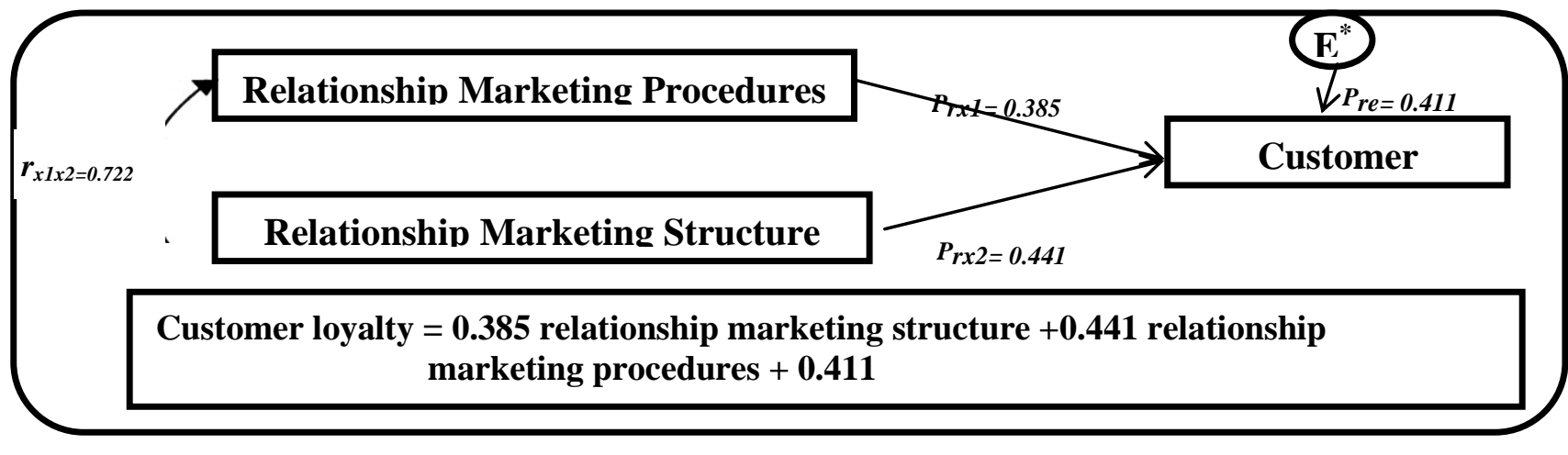




\section{Study Limitations}

The study was conducted on applying the relationship marketing approach in the university hotels at Middle Egypt region (Assiut - Minia - Beni Suef - Fayoum). The previous hotels were selected as an example of the university hotels due to the repeated complaints from their customers (according to the pilot study results); additionally, as well as geographical proximity and lack of interest in researches applied to middle Egypt hotels, especially university hotels.

The field study was organized in interviews with the hotel managers and their assistants, in addition to distribution of customer questionnaires that were judged by experts during the period from March to July 2017

\section{Conclusion and future research implications}

Relationship marketing is an important tool to help overcome the marketing challenges of environmental changing, The research method adopted in this research combined two techniques; the first one was semi-structured interviews with the general managers and their assistants of university hotels. The second technique was the questionnaire survey for university hotels' customers. A five-dimensional Likert scale was used to determine the attitude of the respondents about the study variables. The validity and reliability of the study tools were practically measured by presenting them to a group of industry experts and statistical experts, as well as they statistically measured by using both the Factor Analysis test and Cronbach's Alpha coefficient. The Cochran's formula was used to determine the optimal sample size based on the pilot study results. The sample of the study consists of number of all eight managers and assistant managers of university hotels and number of 203 of university hotels customers. The data collected was analyzed statistically using SPSS version 21. The results of the study indicated that: the relationship marketing procedures influences significantly on the customer loyalty independent of the structure of relationship marketing system at university hotels, there are significant differences between the level of structure of relationship marketing system applied at university hotels and the standard level, there are significant differences between the level of relationship marketing procedures at university hotels and the standard level, there are significant differences between university hotels at Middle Egypt with regard to the level of relationship marketing procedures, there are significant difference between managers and customer's overview concerning the level of relationship marketing procedures applied at university hotels and there are high levels of limitations in the use of relationship marketing with $95 \%$ confidence interval for mean at university hotels. For further researches, it is suggested to test the significance relationship between the study variables (marketing relationship structure and marketing relationship procedures) on guest loyalty at other sectors of hotels. it is also suggested to explore the relationship between customer loyalty and other factors such as (service quality, service rates, and employee's experiences)

\section{Recommendations}

1. The university hotel management should follow the following procedures to achieve relationship marketing:

- Build a detailed database for customers and manage an internal system to serve customers. 
- Building the customer data base on a class basis as each segment of the customer segments represent a relative weight different from the rest of the other segments, where some segments are valuable for the other.

- Search and provide new services to the most valuable customers depending on their needs and desires.

- Developing and modifying many aspects of the University hotel's procedures to meet customer needs such as communication system, providing information, room services, food and beverage service, and dealing with customer complaints.

2. University hotels should conduct a comprehensive survey of their existing customers and target new customers by phone calls, sending e-mails or postcards to enhance their participation in hotel decisions such as deducting price of a service, reducing room rates and meals or take their opinions about the provided services.

3. Providing suitable promotional offers to guests and keep guests informed about everything that is new through the means of media (audio and visual), as well as, means of electronic marketing and social networking sites.

4. Focusing permanently on positive word of mouth use among the employees of the university hotels and among the hotel customers, this is achieved through the nature of the relations between the word of mouth parties in terms of the quality and nature of provided information and services.

5. Training and developing the university hotels workers skills in the manner of dealing with customers, this is reflected in the service quality and thus the relationship marketing success.

6. Application of the tested study model and equation to develop the relationship marketing structure and procedures in order to achieve positive impact on the loyalty of customers at the university hotels.

\section{$\underline{\text { References }}$}

Abdul-Rahman, M., and Kamarulzaman, Y. (2012),"The Influence of Relationship Quality and Switching Costs on Customer Loyalty in the Malaysian Hotel Industry", Procedia - Social and Behavioral Sciences, Vol. 62, 1023 - 1027.

Abd Wahab, N., Abu Hassan, L. F., Shahid, S. A. M., and Maon, S. N. (2016)," The Relationship between Marketing Mix and Customer Loyalty in Hijab Industry: The Mediating Effect of Customer Satisfaction", Procedia Economics and Finance, Vol. 37, 366 - 371.

Akintuned, A. (2012), "Path Analysis Step by Step Using Excel", Journal of Technical Science and Technologies, Vol. 1, 9-15.

Badi, S., Wang, L., and Pryke, S. (2016), "Relationship Marketing in Guanxi Networks: A social Network Analysis Study of Chinese Construction Small and Medium-Sized Enterprises", Journal of Industrial Marketing Management, Vol. 10, $1-15$.

Baran, R. J., Strunk, D. P., and Galka, R. J. (2008),"Principles of Customer Relationship Management", Ohio, Thomson South-Western.

Berry, L.L. (1995),"Relationship Marketing of Services-Growing Interest, Emerging Perspectives", Journal of the Academy of Marketing Science, Vol. 23, Issue, 4, 236 - 245.

Bilgihan, A. (2016)," Gen Y Customer Loyalty in Online Shopping: An Integrated Model of Trust, User Experience and Branding", Journal of Computers in Human Behavior, Vol. 61, 103 - 113. 
Brunner, T.A., Stocklin, M., and Opwis, K. (2009),"Satisfaction, Image and Loyalty: New Versus Experienced Customers", European Journal of Marketing, Vol. 42, Issue 10, 1095-1105.

Buttle, F. (2006),"Customer Relationship Management: Concept and Tools", Oxford, Elsevier Butterworth Heinemann.

Cacciolatti, L., and Lee, S. H. (2016),"Revisiting the Relationship between Marketing Capabilities and Firm Performance: The Moderating Role of Market Orientation, Marketing Strategy and Organizational Power", Journal of Business Research, Retrieved from: http://dx.doi.org/10.1016/j.jbusres.2016.03.067

Clemes, M.D., Wu, J.H.C., Hu, B.D., and Gan, C. (2009). An Empirical Study of Behavioral Intentions in the Taiwan Hotel Industry", Journal of Innovative Marketing, Vol. 5, Issue 3, 30-50.

Countryman, C.C., and Jang, S.C. (2006),"The Effects of Atmospheric Elements on Customer Impression: The Case of Hotel Lobbies", International Journal of Contemporary Hospitality Management, Vol. 18 Issue 7, 534-545.

DebBrown (2017), “What is a Relationship Marketing Plan?” Retrieved from:http://touchyourclientsheart.com/relationship-marketing-plan/

Dolnicar, S., and Ring, A. (2014),"Tourism Marketing Research: Past, Present and Future", Annals of Tourism Research, Vol. 47, $31-47$.

Fabrigar, R.L., Wegener, W.T., MacCallum, C.R., and Strahan,J.E., (1999), "Evaluating the Use of Exploratory Factor Analysis in Psychological Research", Psychological Methods, Vol. 4,272-299.

Gronroos, C. (2009),"Marketing as Promise Management: Regaining Customer Management for Marketing", Journal of Business and Industrial Marketing, Vol. 24, 351-359.

Gummesson, E. (2004),"Return on Relationship (ROR): The Value of Relationship Marketing and CRM in Businessto-Business Context", Journal of Business and Industrial Marketing, Vol.19, Issue 2, 136-148.

Gummesson, E., and Mele, C. (2010)' "Marketing as Value Co-creation through Network Integration and Resource Integration", Journal of Business Market Management, Vol. 4, No. (4), 181-198.

Han, H., and Ryu, K. (2009),"The Roles of the Physical Environment, Price Perception, and Customer Satisfaction in Determining Customer Loyalty in the Restaurant Industry", Journal of Hospitality and Tourism Research, Vol. 33, Issue 4, 487-510.

Hashem, T. N. (2012),"The Impact of Customer Relationship Marketing on Costumers' Image for Gordian Five Star Hotels", International Journal of Business and Social Science, Vol. 3, Issue 2, 129 - 134.

Henry, C. D. (2000),"Is Customer Loyalty a Pernicious Myth?", Business Horizons Journal, Vol. 43, Issue, 4, $13-16$.

Henson, R.K., (2001), "Understanding Internal Consistency Reliability Estimates: A Conceptual Primer on Coefficient Alpha", Measurement and valuation in Counseling and Development, Vol. 34,177-188.

Huang, M. H. (2015),"The Influence of Relationship Marketing Investments on Customer Gratitude in Retailing", Journal of Business Research, Vol. 68, 1318-1323.

Ineson, E. M., Benke, E., and Laszlo, J. (2013),' "Employee loyalty in Hungarian Hotels", International Journal of Hospitality Management, Vol. 32, 31-39.

Jani, D., and Han, H. (2011),"Investigating the Key Factors Affecting Behavioral Intentions: Evidence from a fullService Restaurant Setting", International Journal of Contemporary Hospitality Management, Vol. 23, Issue 7, 10001018.

Jani, D., and Han, H. (2014),"Personality, Satisfaction, Image, Ambience, and Loyalty: Testing their Relationships in the Hotel Industry", International Journal of Hospitality Management, Vol. 37, 11- 20. 
Kim, W. G., and Cha, Y. (2002),"Antecedents and Consequences of Relationship Quality in Hotel Industry", Journal of Hospitality management, Vol. 21, $321-338$.

Kotler, P. (2000),"Marketing Management", $10^{\text {th }}$ Edition, New Jersey, Prentice-Hall.

Lacey, R., Suh, J., and Morgan, R.M. (2007),"Differential Effects of Preferential Treatment Levels on Relational Outcomes", Journal of Service Research, Vol. 9, Issue 3, 241-256.

Lai, F., Griffin, M., and Babin, B.J. (2009),"How Quality, Value, Image, and Satisfaction Create Loyalty at a Chinese Telecom", Journal of Business Research, Vol. 62, 980-986.

Lee, G. S., Tsang, N., and Pan, S. (2015)," Examining the Differential Effects of Social and Economic Rewards in a Hotel Loyalty Program", International Journal of Hospitality Management, Vol. 49, 17-27.

Lim, S., and Lee, B. (2015)," Loyalty Programs and Dynamic Consumer Preference in Online Markets", Decision Support Systems Journal, Vol. 78, $104-112$.

Lin, Y. L., (2010),"The Relationship of Consumer Personality Trait, Brand Personality and Brand Loyalty: An Empirical Study of Toys and Video Games Buyers", Journal of Product and Brand Management, Vol. 19, Issue 1, 417.

MacKinnon, P.D, Fairchild J.A., and Fritz S.M., (2007), "Mediation Analysis", Annual Review of Psychology, Vol. 58, 593-614.

McKercher, B., Denizci-Guillet, B., and Ng, E. (2012)," Rethinking Loyalty", Annals of Tourism Research, Vol. 39, Issue 2, 708-734.

Milfelner, B., Korda, A.P. (2011)," Hotel Image and Guest Satisfaction as a Source of Sustainable Competitive Advantage", International Journal of Sustainable Economy, Vol. 3, Issue 1, 92-106.

Nguyen, N. (2006), “The Collective Impact of Service Workers and Services Cape on the Corporate Image Formation”, Hospitality Management Journal, Vol. 25, 227-244.

Nodstokke, W.D., and Zumbo, D.B., (2010), “A New Nonparameteric levene test for Equal Variances, Psicolegica Vol. 31, 401-430.

Orth, U.R., Limon, Y., and Rose, G. (2010),"Store-Evoked Affect, Personalities, and Consumer Emotional Attachment to Brands", Journal of Business Research, Vol. 63, 1202-1208.

Palmatier, R.W., Dant, R.P., Grewal, D., and Evans, K.R. (2006),"Factors Influencing the Effectiveness of Relationship Marketing: a Meta-Analysis", Journal of Marketing, Vol. 70, No. 4, 136-153.

Palmatier, R.W., Jarvis, C.B., Bechkoff, J.R., and Kardes, F.R. (2009), "The Role of Customer Gratitude in Relationship Marketing", Journal of Marketing, Vol. 73, No. 5, 1-18.

Paula, A. S., Mario R., and Efigenio, R., (2012), "Advantages, Limitations and Solutions in the Use of ERP Systems (Enterprise Resource Planning) - A Case Study in the Hospitality Industry", Procedia Technology, Vol. 5, 264 - 272.

Rashid, T. (2003),"Relationship Marketing: Case Studies of Personal Experiences of Eating Out", British Food Journal, Vol. 105 No. 10, 742 - 750 .

Seymour, T. (2012), “10 Steps to Effective Relationship Marketing”, Retrieved from: http://www.sitepronews.com/2012/10/30/10-steps-to-effective-relationship-marketing/

Shi, Y., Prentice, C., and He, W. (2014),"Linking Service Quality, Customer Satisfaction and Loyalty in Casinos, Does Membership Matter?” International Journal of Hospitality Management, Vol. 40, 81-91.

Smith, B. (1998),"Buyer-Seller Relationship: Bonds, Relationship Management, and Sex Type", Canadian Journal of Administrative Sciences, Vol. 15, Issue, 1, 76. 
Srivastava, R. K., and Reibstein, D. J. (2005),"Metrics for Linking Marketing to Financial Performance", Marketing Science Institute, Retrieved from:

http://bear.warrington.ufl.edu/CENTERS/MKS/invited/Metrics\%20for\%20Linking\%20Marketing\%20to\%20Financia $1 \% 20$ Performance.pdf

Tripadvisor, (2015)," How to Attract the Gen Y Hotel Guest", Retrieved from: https:// www.tripadvisor.com/TripAdvisorInsights/n2038/how-attract-gen-y-hotelguest

Vargo, S.L., and Lusch, R.F., (2004),"Evolving to a New Dominant Logic for Marketing", Journal of Marketing, Vol. 68 , issue $1,1-17$.

Zakaria, I., Ab. Rahman, B., Othman, A. K., Azlina, N., Yunus, M., Dzulkipli, M. R., and Osman, M. A. F. (2014),"The Relationship between Loyalty Program, Customer Satisfaction and Customer Loyalty in Retail Industry: A Case Study", Procedia Social and Behavioral Sciences, Vol. 129, 23 - 30.

شكيب، باثماني، (2014)، "در اسة تحليلية مقارنة للصيغ المستخدمة في حساب حجم العينة العشو ائية"، مجلة جامعة تشرين للبحوث و الدر اسات العلمية،

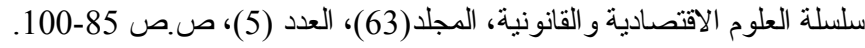

